\title{
Two Cases of "Celox" Gauze Application to Control Bleeding from the Canine Popliteal Artery
}

\section{(İki Köpekte Popliteal Arter Kanamasının Kontrolü Iç̧in “Celox" Gazlı Bez Uygulaması)}

\author{
Zbigniew ADAMIAK ${ }^{1, a}$ Paweł JASTRZĘBSKI ${ }^{2, b}$ Joanna GŁODEK ${ }^{1, c}$ Angelika TOBOLSKA ${ }^{1, d} \&$ \\ ${ }^{1}$ University of Warmia and Mazury in Olsztyn, Faculty of Veterinary Medicine, Department of Surgery and Radiology, \\ Oczapowskiego 14, 10-719 Olsztyn, POLAND \\ ${ }^{2}$ University of Warmia and Mazury in Olsztyn, Faculty of Health Science, Department of Emergency Medicine, Żołnierska \\ 14, 10-561 Olsztyn, POLAND \\ a ORCID: 0000-0001-8350-0198; b ORCID: 0000-0002-0994-7044; ' ORCID: 0000-0003-1395-4084; d ORCID: 0000-0001-9926-509X
}

Article Code: KVFD-2020-24022 Published Online: 20.02 .2020

How to Cite This Article

Adamiak Z, Jastrzębski P, Głodek J, Tobolska A: Two cases of "Celox" gauze application to control bleeding from the canine popliteal artery. Kafkas Univ Vet Fak Derg, 26 (3): 453-454, 2020. DOI: 10.9775/kvfd.2020.24022

\section{Dear Editor,}

Severe arterial bleeding caused by trauma is potentially life-threatening and requires immediate surgical attention. Many life-saving procedures in veterinary practice are based on the solutions that have been developed in human medicine. One of such procedures relies on hemostatic dressings to manage profuse bleeding from large vessels ${ }^{[1,2]}$. Hemostatic dressings form a micro-adhesive physical barrier by absorbing water from the blood, activating platelets and increasing clotting capabilities at the site of injury. Celox Gauze contains chitosan granules which effectively stop bleeding from arteries. Chitosan works independently of the physiological clotting mechanism and produces a hemostatic plug by binding to red blood cells and platelets ${ }^{[3-5]}$. This lettering describes the use of the Celox Gauze hemostatic dressing for controlling bleeding from an injured popliteal artery in two dogs.

Celox gauze was applied in two dogs: a male Rottweiler aged 5 years with body weight of $46 \mathrm{~kg}$ and a male German Shepherd aged 6 years with body weight of $39 \mathrm{~kg}$. Both patients had undergone surgical treatment of anterior cruciate ligament injury. In both cases, the popliteal artery was damaged when the surgical band was passed behind the lateral condyle of the femur with the use of a sharp surgical needle during the stabilisation of the knee joint. Immediately after injury, the wound was compressed with sterile tampons on the lateral side of the popliteal fossa. The tampons were removed, and the Celox Gauze hemostatic dressing (MedTrade Products Ltd., Crewe, UK) was applied approximately 3 min later. Celox Gauze was tightly packed in the wound cavity, covered with sterile tampons and manually compressed. The compression time was approximately $20 \mathrm{~min}$. The tampons were observed for around 2 min to monitor signs of bleeding. None of the tampons absorbed blood. Celox Gauze was carefully removed, and the wound was observed for approximately $3 \mathrm{~min}$. Hemostasis was effectively achieved in both cases. Surgical repair of anterior cruciate ligament injury was continued. The injured popliteal artery was not sutured. Soft tissues in the surgical site were tightly sutured. Both dogs were intravenously administered Sterofundin (Braun, Melungen, Germany) at $5 \mathrm{~mL} / \mathrm{kg} / \mathrm{h}$ throughout surgery, and the dose was increased to $10 \mathrm{~mL} / \mathrm{kg} / \mathrm{h}$ during haemorrhage control. The temperature of the operated limb was monitored for two days after the procedure.

Both dogs achieved normal limb loading 6 weeks after surgery, and the owners were satisfied with the outcome. The temperature of the operated limb was normal during examinations performed 2 and 4 weeks after the procedure. Infections of the skin or subcutaneous tissues were not observed in the surgical site. The area of the wound was not swollen or bruised. One year after surgery, the Rottweiler was again admitted to the clinic for surgical treatment of anterior cruciate ligament injury in the other limb.

There is a general scarcity of published research into the

\footnotetext{
if iletişim (Correspondence)

限 +48697935047

angelika.tobolska@uwm.edu.pl
} 
use of hemostatic dressings in dogs. A hemostatic dressing containing chitosan acetate was successfully applied to control bleeding from the canine femoral artery ${ }^{[6]}$. Chitosan-based hemostatic dressings were also effectively used in rats ${ }^{[5,7]}$. The application of hemostatic dressings in pigs was more extensively researched ${ }^{[8-10]}$. Kozen et al. ${ }^{[4]}$ reported that Celox Gauze was as effective as two other hemostatic dressings, and it significantly improved survival rates in comparison with standard dressings. In contrast, in the different study observed no differences in the effectiveness of standard gauze dressings and other hemostatic dressings applied to small wounds that were caused by penetrating injuries in sites that were difficult to compress ${ }^{[11]}$. In both described cases, hemostasis was effectively achieved with Celox Gauze. The evaluated dressing was applied to the wound for 20 min without causing soft tissue irritation in the wound area. After an injury to the popliteal artery, blood was supplied to the thigh mainly by the deep femoral artery.

As a result, in this lettering, the clinical outcomes in the presented cases indicate that the Celox Gauze hemostatic dressing effectively controls bleeding from the canine popliteal artery.

\section{REFERENCES}

1. Wedmore I: Prehospital and enroute care. In, Front Line Surgery, 1-16, Springer, New York, NY, 2010. DOI: 10.1007/978-1-4419-6079-5_1

2. Zideman DA, De Buck EDJ, Singletary EM, Cassan $P$, Chalkias AF, Evans TR, Hafner CM, Handley AJ, Meyran D, Schunder-Tatzber S, Vandekerckhove PG: European resuscitation council guidelines for resuscitation 2015 section 9. First aid. Resuscitation, 95, 278-287, 2015.

\section{DOI: 10.1016/j.resuscitation.2015.07.031}

3. Prashanth KVH, Tharanathan RN: Chitin/chitosan: Modifications and their unlimited application potential-an overview. Trends Food Sci Technol, 18 (3): 117-131, 2007. DOI: 10.1016/j.tifs.2006.10.022

4. Kozen BG, Kircher SJ, Henao J, Godinez FS, Johnson AS: An alternative hemostatic dressing: Comparison of CELOX, HemCon, and QuikClot. Acad Emerg Med, 15 (1): 74-81, 2008. DOI: 10.1111/j.15532712.2007.00009.x

5. Chan LW, Kim CH, Wang X, Pun SH, White NJ, Kim TH: PolySTATmodified chitosan gauzes for improved hemostasis in external hemorrhage. Acta Biomater 31, 178-185, 2016. DOI: 10.1016/j.actbio.2015.11.017

6. Szatmári V: Chitosan hemostatic dressing for control of hemorrhage from femoral arterial puncture site in dogs. J Vet Sci, 16 (4): 517-523, 2015. DOI: 10.4142/jvs.2015.16.4.517

7. Koksal O, Ozdemir F, Cam Etoz B, Isbil Buyukcoskun N, Sıgırlı D: Hemostatic effect of a chitosan linear polymer (Celox $\left.{ }^{\oplus}\right)$ in a severe femoral artery bleeding rat model under hypothermia or warfarin therapy. Ulus Travma Acil Cerrahi Derg, 17 (3): 199-204, 2011. DOI: 10.5505/ tjtes.2011.88155

8. Adamiak Z, Jastrzębski P, Pomianowski A, Otrocka-Domagała I, Holak P, Zhalniarovich Y, Przyborowska P, Głodek J: Effect of 24 hour application of three hemostatic dressings to porcine thigh muscles. Pol J Vet Sci, 17 (3): 519-521, 2014. DOI: 10.2478/pjvs-2014-0076

9. Adamiak Z, Borys J, Krystkiewicz W, Pomianowski A, Jałyński M, Holak P, Brzeziński M, Jastrzębski P, Tobolska A, Głodek J: The Effect of haemostatic dressing prototypes for the emergency services in the porcine haemostatic system. In Vivo, 33 (2): 359-363, 2019. DOI: 10.21873/ invivo. 11482

10. Jastrzębski P, Adamiak Z, Pomianowski A, Krystkiewicz W, Holak P, Sawicki S, Przyborowska P, Zhalniarovich Y, Gudzbeler G: Response of the coagulation system after application of hemostatic dressings in an animal model. Pol J Vet Sci, 17 (4): 725-727, 2014. DOI: 10.2478/pjvs-2014-0106

11. Littlejohn LF, Devlin JJ, Kircher SS, Lueken R, Melia MR, Johnson AS: Comparison of Celox-A, ChitoFlex, WoundStat, and combat gauze hemostatic agents versus standard gauze dressing in control of hemorrhage in a swine model of penetrating trauma. Acad Emerg Med, 18 (4): 340-350, 2011. DOI: 10.1111/j.1553-2712.2011.01036.x 